\title{
Analisis Sentimen Pengguna Instagram Terhadap Kebijakan Kemdikbud Mengenai Bantuan Kuota Internet dengan Metode Support Vector Machine (SVM)
}

Syifa Rahmawati Hakim,

Politeknik Statistika STIS,211710025@stis.ac.id

M. Alfa Rizki,

Politeknik Statistika STIS, 211709802@stis.ac.id

Noval Irgi Zekha F,

Politeknik Statistika STIS,211709902@stis.ac.id

Nurhidayatul Fitri,

Politeknik Statistika STIS, 211709916@stis.ac.id

Yolanda Rizkie A,

Politeknik Statistika STIS, $211710071 @$ @stis.ac.id

Rani Nooraeni

raninoor@stis.ac.id

ABSTRAK, Respons masyarakat Instagram sebanyak 1483 komentar terhadap kebijakan Kemdikbud mengenai pemberian bantuan kuota internet selama masa pandemic COVID-19 diidentifikasi menjadi $70.67 \%$ sentimen positif dan $29.33 \%$ sentiment negatif. Kemudian respons tersebut diklasifikasikan menggunakan data awal (keseluruhan data), data training, dan data testing dengan model SVM Radial (RBF) menghasilkan rata-rata persentase komentar berupa sentiment positif dari klasifikasi penggunaan data awal, data training, dan data testing sebanyak $61.5 \%$. Hal tersebut menunjukkan respons yang baik dan rasa berterimakasih para pengguna Instagram terhadap adanya kebijakan Kemdikbud mengenai pemberian bantuan kuota internet selama masa pandemic COVID-19. Sedangkan 38.5\% lainnya merupakan komentar berupa sentimen negatif yang menunjukkan keluh kesah pasa pengguna Instagram terhadap kendala-kendala dalam kebijakan Kemdikbud mengenai pemberian bantuan kuota internet selama masa pandemi COVID-19. Model SVM Radial (RBF) mampu melakukan pengklasifikasian respons pengguna Instagram terkait pemberian bantuan kuota internet dengan cukup baik. Hal tersebut dibuktikan dengan nilai evaluasi model berupa tingkat akurasi sebesar 79.67\%, sensitivitas sebesar $78.89 \%$, dan spesifisitas sebesar $81.82 \%$. Dengan demikian, respons masyarakat yang salah satunya diwakili oleh pengguna media sosial seperti Instagram dapat menjadi sumber informasi dan data alternatif untuk menunjang evaluasi dan perbaikan kebijakan pemerintah yang sudah ada maupun pembuatan kebijakan pemerintah di masa yang akan datang.

Kata Kunci: COVID-19, bantuan kuota Kemdikbud, analisis sentimen, SVM.

\section{PENDAHULUAN}

Saat ini virus corona atau yang lebih dikenal sebagai virus yang menyerang sistem saluran pernapasan baik pada manusia maupun hewan, masih menjadi penyakit yang sangat diwaspadai. Beberapa jenis coronavirus sebelumnya diketahui menyebabkan penyakit Middle East Respiratory Syndrome (MERS) dan Severe Acute Respiratory Syndrome (SARS), namun beberapa waktu belakang ditemukan jenis coronavirus terbaru yang menyebabkan penyakit COVID-19. Virus yang baru ditemukan tersebut bermula dari daerah Wuhan, Tingkok yang kemudian menyebar sangat cepat sehingga menjadi wabah disana dan kemudian menjadi suatu pandemi baru di seluruh dunia karena kecepatan penyebaran virus yang melalui teteasan kecil (droplet) dari hidung atau mulut pada saat batuk atau bersin yang apabila mengenai benda-benda disekitar akan bertahan disana dan jika tersentuh akan menjadi salah satu factor penyebaran juga.

Virus corona sudah dikategorikan sebagai pandemi yang artinya wabah penyakit tersebut sudah meluas hingga ke berbagai negara di seluruh dunia bukan hanya Wuhan, tempat bermulanya wabah virus corona. Dengan kata lain, penyakit COVID-19 sudah menjadi masalah bersama bagi seluruh warga di dunia. 
Pengertian wabah sendiri menurut ahli epidemiologi, Wabah terjadi ketika suatu penyakit mulai menyebar dan menulari penduduk dengan jumlah lebih banyak daripada biasanya di dalam suatu area atau komunitas atau saat musim-musim tertentu. Wabah biasanya berlangsung dalam jangka waktu lama, mulai dari hitungan hari hingga tahun. Tidak hanya di satu wilayah, tetapi wabah juga bisa meluas ke daerah atau negara lain di sekitarnya. Namun, tidak semua penyakit menular dapat disebut sebagai wabah. Suatu penyakit dapat dikatakan wabah ketika penyakit tersebut memiliki kondisi, yaitu sudah lama tidak muncul dan menjangkiti masyarakat, datang penyakit baru yang sebelumnya tidak diketahui, atau penyakit tersebut baru pertama kali menjangkiti masyarakat di daerah tersebut. Dikarenakan virus corona termasuk dalam salah satu kondisi tersebut maka dapat dikategorikan sebagai wabah baru.

Pandemi virus corona yang sudah meluas ke hampir seluruh penjuru dunia tentunya memberikan dampak pada berbagai lini kehidupan, termasuk sektor ekonomi, sosial, pariwisata, dan pendidikan. Pada segmen pendidikan, banyak negara yang menutup institusi pendidikan termasuk Indonesia untuk mengurangi kontak orang-orang secara masif. Pelaksanaan pendidikan di Indonesia mengalami perubahan yang cukup signifikan, salah satunya diterapkan system pendidikan berupa Pembelajaran Jarak Jauh (PJJ) yang masih sangat asing di Indonesia. Pembelajaran Jarak Jauh menjadi salah satu solusi terbaik saat ini, mengingat perkembangan dari teknologi informasi dan komunikasi yang semakin maju. Sarana pembelajaran dapat menggunakan aplikasi zoom, google meet, google classroom, youtube, maupun whatsapp.

Namun, dikarenakan system Pembelajaran Jarak Jauh (PJJ) yang masih sangat asing bagi warga Indonesia, tidak menutup kemungkinan menimbulkan beberapa masalah terkait pelaksanaannya. Dengan system baru ini, tentunya semua peserta didik dan tenaga pendidik diharuskan memiliki akses internet yang baik. Namun masih banyak wilayah-wilayah di Indonesia yang memiliki keterbatasan dalam mengakses internet baik jaringan internet yang buruk, terkendala pada internet karena keterbatasan ekonomi, maupun teknologi yang kurang memadai sehingga menjadi kendala berlangsungnya kegiatan belajar-mengajar.

Untuk mengatasi hal tersebut, Kementrian Pendidikan dan Kebudayaan (Kemdikbud) menetapkan beberapa kebijakan baru untuk menyesuaikan serta menjadi solusi di masa pandemi COVID-19 saat ini, salah satunya pemberian dana Bantuan Operasional Sekolah guna membiayai keperluan pengadaan barang serta membiayai pembelajaran secara daring atau jarak jauh. Dengan adanya Bantuan Operasional Sekolah tersebut, satuan pendidikan diberikan kewenangan untuk mengalokasikan dana tersebut untuk penyediaan kuota bagi peserta didik dan tenaga pendidik yang tertuang dalam Peraturan Menteri Pendidikan dan Kebudayaan (Permendikbud) Nomor 19 Tahun 2020 tentang Perubahan Permendikbud Nomor 8 Tahun 2020 tentang Petunjuk Teknis Reguler, yang diterbitkan pada 9 April 2020 lalu. Hal ini sebagai jawaban atas kecemasan masyarakat di tengah kesulitan ekonomi akibat terdampak pandemi.

Kebijakan baru Kemdikbud yang memberikan dana bantuan untuk penyediaan atau bantuan kuota tersebut menimbulkan berbagai respons dari masyarakat. Sebagian besar masyarakat memberikan respons positif terhadap kebijakan tersebut dengan menyetujui dan mendukung Kemdikbud dalam mewujudkannya, namun tak sedikit juga masyarakat yang memberikan respons negatif. Respons masyarakat terkait hal tersebut dapat terlihat dalam komentar mereka di setiap postingan instagram pihak Kemdikbud yang berkaitan dengan bantuan kuota internet.

Berdasarkan latar belakang tersebut, maka pada penelitian ini ingin melihat bagaimana respons masyarakat terhadap kebijakan Kemdikbud mengenai bantuan kuota internet dengan menggunakan data dari komentar instagram. Untuk menjawab permasalahan tersebut akan dilakukan analisis sentimen yang merupakan proses pengklasifikasian text ke dalam sentimen positif dan negatif menggunakan metode Support Vector Machine (SVM). Sehingga tujuan penelitian ini adalah untuk mengidentifikasi dan mengklasifikasikan respons masyarakat terkait kebijakan bantuan kuota internet dari Kemdikbud menggunakan SVM. 


\section{TINJAUAN PUSTAKA}

\section{Text Mining}

Text mining merupakan proses analisis teks yang dilakukan secara otomatis oleh komputer yang bertujuan untuk mendapatkan informasi yang berkualitas dari teks yang terangkum dalam sebuah dokumen. Prosedur utama dalam metode ini terkait dengan menemukan kata-kata yang dapat mewakili isi dari dokumen untuk selanjutnya dilakukan analisis keterhubungan antar dokumen dengan menggunakan metode statistik tertentu seperti analisis kelompok, klasifikasi dan asosiasi (Han \& Kamber, 2006).

Langkah-langkah yang dilakukan dalam text mining adalah sebagai berikut (Kurniawan, et al. 2012):

\section{Text Preprocessing}

Tindakan yang dilakukan pada tahap ini meliputi tolowercase dan tokenizing;

\section{Feature Selection}

Tindakan yang dilakukan pada tahap ini ialah menghilangkan stopword dan stemming.

\section{Analisis Sentimen}

Analisis Sentimen atau dapat disebut sebagai opinion mining adalah bidang studi dalam menganalisis pendapat orang, evaluasi, penilaian, sikap dan emosi terhadap suatu entitas seperti produk, jasa, organisasi, individu, isu-isu, peristiwa dan topik. (Julianto, et al. 2017). Analisis ini digunakan untuk mendapatkan suatu informasi tertentu dari suatu kumpulan data yang ada. Analisis sentimen berfokus pada pengolahan opini yang mengandung polaritas, yaitu memiliki nilai sentimen positif ataupun negatif (Novantirani, et al. 2014).

Pemberian label kelas sentimen dilakukan dengan menggunakan Lexcion Based Features. Kemudian dilakukan pencarian nilai sentimen dalam suatu kalimat dengan rumus :

$$
\begin{aligned}
S_{\text {positive }} & =\sum_{\substack{i=1 \\
n}}^{n} \text { positive score }_{i} \\
S_{\text {negative }} & =\sum_{i=1}^{n} \text { negative score }_{i}
\end{aligned}
$$

Keterangan :

$S_{\text {positive }}:$ Jumlah kata opini positif

\section{$S_{\text {negative }}$ : Jumlah kata opini negatif}

Sehingga dalam satu kalimat dapat diketahui jumlah nilai positif dan negatif dari tiap kata penyusunnya. Selanjutnya akan dilakukan perbandingan untuk menentukan kalimat tersebut masuk dalam sentimen positif atau negatif.

$$
\text { kelas sentimen }\left\{\begin{array}{l}
\text { positif jika } S_{\text {positive }}>S_{\text {negative }} \\
\text { netral jika } S_{\text {positive }}=S_{\text {negative }} \\
\text { negatif jika } S_{\text {positive }}<S_{\text {negative }}
\end{array}\right.
$$

\section{Support Vector Machine (SVM)}

Support Vector Machine adalah sebuah metode seleksi yang membandingkan parameter standar seperangkat nilai diskrit yang disebut kandidat set, dan mengambil salah satu yang memiliki akurasi klasifikasi terbaik (Dong, Xia, Tu, \& Xing, 2007). SVM termasuk ke dalam supervised learning. Adapun karakteristik dari Support Vector Machine ialah sebagai berikut:

1. Support Vector Machine adalah linier classifier

2. Pattern Recognition dilakukan dengan mentransformasikan data pada input space ke ruang yang berdimensi lebih tinggi, dan optimasi dilakukan pada ruang vector yang baru.

3. Menerapkan strategi Structural Risk Minimization (SRM).

4. Prinsip kerja Support Vector Machine pada dasarnya hanya mampu menangani klasifikasi dua kelas.

Untuk mengatasi kasus yang nonlinier, dapat digunakan metode kernel. Fungsi kernel yang biasa digunakan dalam Support Vector Machine (SVM) antara lain (Pudjiarti, 2016) :

1. Linear:

2. Polinomial:

$$
x^{T} x
$$

3. Radial basis function(RBF) :

$$
\left(x^{T} x_{i}+1\right)^{P}
$$

$$
\exp \left(-\frac{1}{2 \sigma^{2}}\left\|x-x_{i}\right\|^{2}\right)
$$

4. Tangent hyperbolic (sigmoid) :

$$
\tanh \left(\beta x^{T} x_{i}+\beta_{1}\right), \text { dimana } \beta, \beta_{1} \in R
$$

\section{Evaluasi Performansi}

Evaluasi performansi dilakukan untuk menguji hasil dari klasifikasi dengan mengukur nilai performansi dari sistem yang telah dibuat. Parameter pengujian yang digunakan untuk 
evaluasi yaitu akurasi yang perhitungannya diperoleh dari tabel confusion matrix.

\begin{tabular}{lcc}
\multicolumn{3}{c}{ TABEL 1. Confusion Matrix } \\
\hline \multirow{2}{*}{ True Class } & \multicolumn{2}{c}{ Predicted Class } \\
& Positif & Negatif \\
\hline Positif & TP & FN \\
\hline Negatif & FP & TN \\
Accuracy $(\%)=\frac{T P+T N}{T P+F P+T N+F N}$ \\
Sensitivity $(\%)=\frac{T P}{T P+F N}$ \\
Specificity $(\%)=\frac{T N}{T N+F P}$
\end{tabular}

\section{Penelitian Terkait}

Penelitian mengenai opini masyarakat menggunakan metode analisis sentimen sebelumnya cukup banyak dilakukan. Salah satunya penelitian yang dilakukan oleh Novantirani, et al di Indonesia untuk mengklasifikasikan opini masyarakat mengenai penggunaan transportasi umum darat dalam kota berdasarkan cuitan di twitter menggunakan metode Support Vector Machine.

Penelitian analisis sentimen lainnya dilakukan oleh Buntoro pada tahun 2016 mengenai hatespeech pada twitter yang membandingkan hasil akurasi metode Naive Bayes Classifier (NBC) dan Support Vector Machine (SVM). Berdasarkan penelitian tersebut didapatkan bahwa hasil akurasi tertinggi didapatkan saat menggunakan metode klasifikasi Support Vector Machine (SVM) dengan nilai rata-rata akurasi mencapai $66,6 \%$

\section{METODOLOGI}

Data yang digunakan pada penelitian ini adalah data komentar pengguna instagram di 7 unggahan akun@kemdikbud.ri yang berkaitan dengan bantuan kuota internet selama masa pandemi COVID-19 mulai tanggal 27 Agustus 30 September 2020 yang diperoleh melalui scraping dengan software spyder dan selenium python. Pemilihan waktu dimulai dari tanggal
27 Agustus 2020 yang didasarkan pada tanggal beredarnya surat bernomor 8202/C/PD/2020 tentang pemberian bantuan kuota internet. Berdasarkan hasil scraping, terkumpul data sebanyak 4520 komentar.

\section{Prosedur Pengolahan Data}

Langkah-langkah pengolahan data dijelaskan sebagai berikut:

1. Prepocessing data

- Text Cleaning

Bertujuan untuk menghilangkan URL, menghapus emoji, mention, hastag, kata-kata slang, dan menghilangkan simbol atau huruf yang tidak relevan

- To Lower Case

Bertujuan mengubah semua karakter huruf menjadi huruf kecil

- Tokenizing

Proses penguraian deskripsi yang semula berupa kalimat - kalimat menjadi kata-kata dan menghilangkan tanda titik(.), $\operatorname{koma}($,$) , spasi dan$ karakter angka yang ada pada kata tersebut

- Remove Stopword

Menghilangkan kosakata yang bukan merupakan ciri (kata unik) dari suatu dokumen. Contoh: dari, yang, dengan, di, ke dan sebagainya.

- Stemming

Bertujuan untuk mereduksi suatu kata ke bentuk dasarnya. Pada proses ini akan dihilangkan imbuhan-imbuhan yang ada pada setiap kata.

2. Pemberian label kelas sentimen

Selanjutnya akan dilakukan analisis sentimen untuk pemberian label apakah suatu kalimat termasuk ke dalam sentimen positif atau sentimen negatif. Proses ini dilakukan dengan Lexcion Based Features, yaitu pendekatan yang menggunakan suatu kamus sentimen berisi kata positif dan kata negatif yang dibandingkan dan dicocokkan dengan kata pada kalimat untuk diketahui tingkat polaritasnya (Peng, 2011).

Cara menentukan kelas sentimen adalah dengan menghitung skor kata opini positif 
dan skor kata opini negatif pada tiap kalimat. Jika total jumlah nilai positif lebih besar dari jumlah nilai negatif maka kalimat akan berorientasi positif. Jika total jumlah nilai positif sama dengan jumlah nilai negatif maka kalimat akan berorientasi objektif atau netral. Namun jika total jumlah nilai positif kurang dari jumlah nilai negatif maka kalimat akan berorientasi negatif (Pamungkas \& Putri, 2016).

3. Wordcloud

Wordcloud merupakan salah satu metode untuk memvisualisasikan data teks. Dengan menggunakan wordcloud, gambaran frekuensi kata-kata dapat ditampilkan dalam bentuk yang menarik dan informatif. Ukuran teks dalam wordcloud menyesuaikan dengan frekuensi data, semakin banyak frekuensi kata, maka semakin besar pula ukuran kata tersebut ditampilkan dalam wordcloud.

4. Klasifikasi dengan Support Vector Machine Setelah pelabelan kelas sentimen, data kemudian dibagi menjadi dua, yaitu data training dan data testing. Data training digunakan untuk mengklasifikasikan sedangkan data testing digunakan untuk mengevaluasi hasil pengklasifikasian dari data training. Evaluasi model yang terbentuk dapat dengan akurasi, presisi, sensitivity, specificity, Kurva ROC dan sebagainya.

\section{PEMBAHASAN}

\section{Identifikasi Respons Masyarakat}

Berdasarkan hasil dari tahapan preprocessing, dihasilkan data sebanyak 1483 komentar (32.81\%) untuk selanjutnya dianalisis. Sebelum memasuki tahap analisis sentimen, dilakukan identifikasi respons/komentar masyarakat sebagai berikut:

\section{Pelabelan Kelas Sentimen}

Pelabelan kelas sentimen dilakukan setelah melewati tahapan preprocessing data dengan melakukan pelabelan yang terdiri atas kelas sentimen positif dan sentimen negatif..
Berikut ditampilkan tabel 2 tentang pelabelan kelas sentimen terhadap data komentar Instagram.

Tabel 2. Contoh Hasil Pelabelan Kelas Sentimen

\begin{tabular}{|c|c|c|}
\hline Komentar & Skor & $\begin{array}{c}\text { Kelas } \\
\text { Sentimen }\end{array}$ \\
\hline $\begin{array}{l}\text { terimakasih mentri } \\
\text { jajaran terlibat program } \\
\text { kapasitas meningkat } \\
\text { beradaptasi tantangan } \\
\text { jam kerja pengalaman } \\
\text { petik peningkatan } \\
\text { kapasitas ops hasilnya } \\
\text { maksimal momentum } \\
\text { kasih judul rubrik } \\
\text { tangguh menguji } \\
\text { kesabaran mengasah } \\
\text { kemampuan bravo jaya } \\
\text { berkonstribusi }\end{array}$ & 4 & Positif \\
\hline $\begin{array}{l}\text { terima kasih menteri } \\
\text { dirjen paud dikdasmen } \\
\text { suara dilapangkan } \\
\text { direspon cepat siswa } \\
\text { bantuan kuota } \\
\text { terkecuali kalo bantuan } \\
\text { kuota data internet } \\
\text { tolong alokasikan } \\
\text { operatoroperator } \\
\text { sekolah tenaga } \\
\text { kependidikan operator } \\
\text { sekolah garda terdepan } \\
\text { mewujudkan data } \\
\text { pokok pendidikan } \\
\text { perhatian ucapkan } \\
\text { terimakasih salam } \\
\text { nusa bangsa data }\end{array}$ & 6 & Positif \\
\hline $\begin{array}{l}\text { maaf pengisian } \\
\text { dapodik kali benar- } \\
\text { benar ribet tinggal } \\
\text { sinkron data benahi } \\
\text { terkunci menghambat } \\
\text { pemberian kuota } \\
\text { mengrus registrasi sdm } \\
\text { verval balasannya } \\
\text { benahi menunggu } \\
\text { menguninstall aplikasi } \\
\text { dapodik mengisi data } \\
\text { siswa }\end{array}$ & -4 & Negatif \\
\hline $\begin{array}{l}\text { kemdikbud dipush } \\
\text { siswa orang tua }\end{array}$ & Negatif & \\
\hline
\end{tabular}




\begin{tabular}{l|l|l}
\hline \multicolumn{1}{c|}{ Komentar } & Skor & $\begin{array}{c}\text { Kelas } \\
\text { Sentimen }\end{array}$ \\
\hline menagih kuota & & \\
kemdikbud push & & \\
operator sekolah & & \\
menyelesaikan & & \\
datanya operator & & \\
kelelahan server & & \\
down dll siswa & & \\
mahasiswa orang & & \\
tua mohon & \\
pengertiannya & & \\
bersabar kuota & & \\
proses kasihan & & \\
operator sekolah & & \\
lihat benar-benar & & \\
istirahat tolong & & \\
bantuan & \\
keluarganya urus \\
data bantuan \\
kuota lelah \\
menyalahkan \\
semoga berjalan \\
lancar
\end{tabular}

Proses pelabelan kelas sentimen dilakukan dengan menghitung frekuensi suatu kata yang digunakan dalam berkomentar oleh pengguna Instagram di 7 unggahan akun @ kemdikbud.ri terkait pemberian bantuan kuota internet selama masa pandemi COVID-19. Tabel 3 menunjukkan beberapa kata dengan frekuensi kemunculan tertinggi yang digunakan oleh para pengguna Instagram dalam berkomentar dan dibedakan berdasarkan kelas sentimen positif dan sentimen negatif.

Tabel 3. Daftar Kata-kata Sentimen Positif dan Negatif Berdasarkan Frekuensi Kemunculan Tertinggi

\begin{tabular}{c|c|c|c}
\hline \multicolumn{2}{c|}{ Sentimen Positif } & \multicolumn{2}{c}{ Sentimen Negatif } \\
\hline Kata & Jumlah & Kata & Jumlah \\
\hline sekolah & 222 & sekolah & 106 \\
\hline bantuan & 206 & verval & 75 \\
\hline guru & 142 & siswa & 64 \\
\hline belajar & 127 & guru & 54 \\
\hline Siswa & 114 & nomor & 51 \\
\hline terimakasih & 112 & susah & 51 \\
\hline Masuk & 94 & data & 47
\end{tabular}

\begin{tabular}{c|c|c|c}
\hline \multicolumn{2}{c|}{ Sentimen Positif } & \multicolumn{2}{c}{ Sentimen Negatif } \\
\hline Kata & Jumlah & Kata & Jumlah \\
\hline Gratis & 83 & operator & 46 \\
\hline
\end{tabular}

Berdasarkan tabel 3, kata yang paling banyak digunakan oleh pengguna Instagram dalam berkomentar di unggahan akun @kemdikbud.ri pada kelas sentimen positif adalah "sekolah" sebanyak 222 kata. Kemudian, secara berturut-turut disusul oleh kata "bantuan", "guru", "belajar", "siswa", "terimakasih", "masuk", dan "gratis". Pada kelas sentimen negatif, kata dengan frekuensi kemunculan tertinggi "sekolah" sebanyak 106 kata, sama dengan kata yang sering muncul pada kelas sentimen positif. Kemudian disusul oleh kata "'verval", "siswa", "guru", "nomor", "susah", "data", dan "operator".

2. Visualisasi Hasil Pelabelan Kelas Sentimen

\section{a. Barplot Sentimen Negatif}

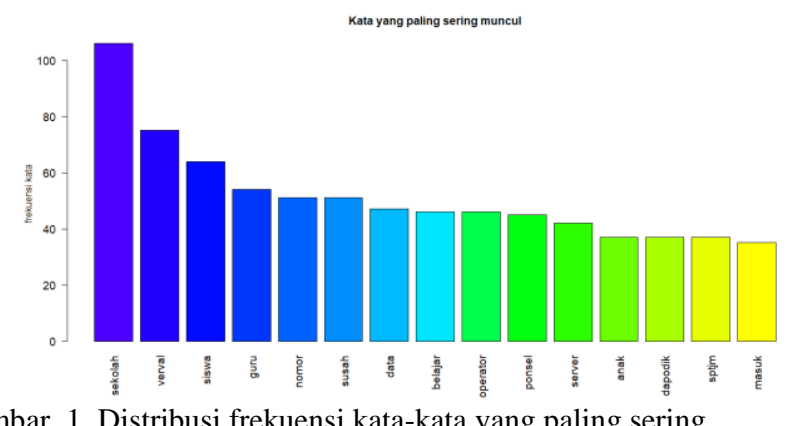

Gambar 1. Distribusi frekuensi kata-kata yang paling sering muncul pada kelas sentimen negatif

Gambar 1 menunjukkan 15 kata yang paling banyak muncul di kelas sentimen negatif pada komentar unggahan akun @kemdikbud.ri terkait pemberian bantuan kuota internet. Katakata tersebut diantaranya adalah sekolah, verval, susah, data, operator, dapodik, dsb. Dimana kata-kata yang telah disebutkan sebelumnya merupakan kata yang paling sering digunakan oleh pengguna Instagram untuk mengomentari unggahan di Instagram terkait kebijakan Kemdikbud dalam memberikan bantuan kuota internet. 


\section{b. Wordcloud Sentimen Negatif}

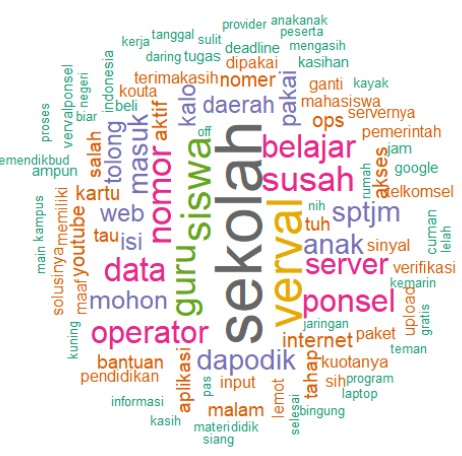

Gambar 2. Wordcloud kelompok kata pada kelas sentimen negatif

Gambar 2 menunjukkan hasil wordcloud dari kata-kata pada kelas sentimen negatif, dimana semakin besar ukuran katanya maka semakin tinggi pula frekuensi kemunculan katanya. Terlihat bahwa kata "sekolah", "verval", "siswa" dan "guru" merupakan kata-kata yang paling sering digunakan para pengguna Instagram dalam mengomentari unggahan Kemdikbud mengenai bantuan kuota internet. Untuk kata-kata yang ukurannya relatif lebih kecil dan sama menunjukkan bahwa penggunaan kata-katanya tidak sebanyak keempat kata tersebut dalam merespon kebijakan Kemdikbud terkait pemberian bantuan kuota internet.

\section{c. Barplot Sentimen Positif}

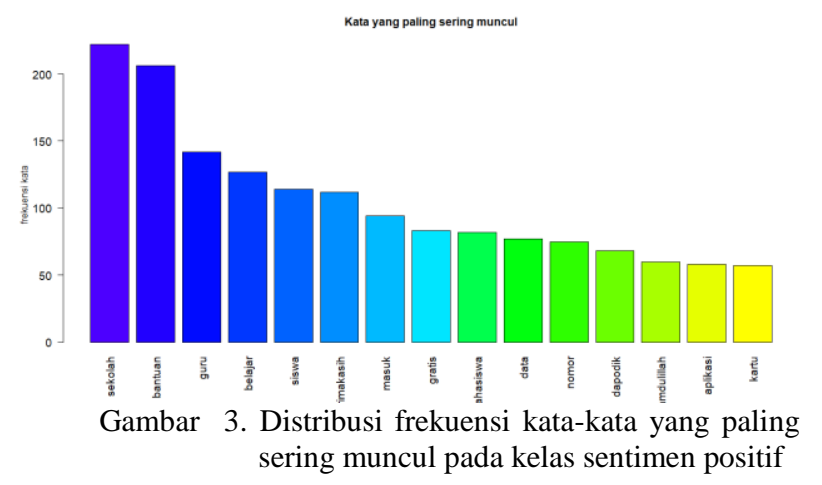

Gambar 3 menunjukkan 15 kata yang paling banyak muncul di kelas sentimen positif pada komentar unggahan akun @kemdikbud.ri terkait pemberian bantuan kuota internet. Dimana kata dengan frekuensi tertinggi kemunculannya adalah "sekolah" sebanyak 222 kata dan "bantuan" sebanyak 206 kata. Katakata yang tertera pada barplot tersebut merupakan kata yang paling sering digunakan oleh pengguna Instagram untuk mengomentari unggahan di Instagram terkait kebijakan Kemdikbud dalam memberikan bantuan kuota internet

\section{d. Wordcloud Sentimen Positif}

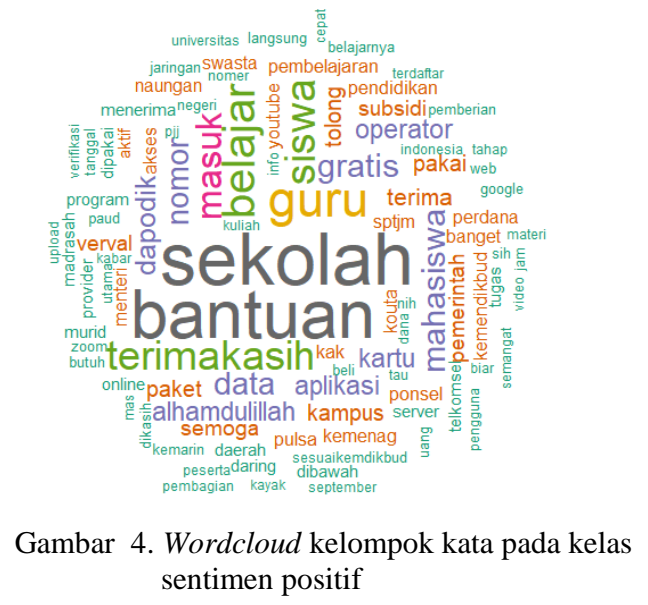

Gambar 4 menunjukkan hasil wordcloud dari kata-kata pada kelas sentimen positif, dimana semakin besar ukuran katanya maka semakin tinggi pula frekuensi kemunculan katanya. Terlihat bahwa kata "sekolah", "bantuan", "guru", dan "terimakasih" merupakan kata-kata yang paling sering digunakan para pengguna Instagram dalam mengomentari unggahan Kemdikbud mengenai bantuan kuota internet. Untuk kata-kata yang ukurannya relatif lebih kecil dan sama menunjukkan bahwa penggunaan kata-kata tersebut tidak sebanyak keempat kata tersebut dalam merespon kebijakan Kemdikbud terkait pemberian bantuan kuota internet.

\section{e. Distribusi Persentase Respons Masyarakat berdasarkan Kelas Sentimen}

Berdasarkan hasil proses pelabelan kelas sentimen pada data yang telah melalui preprocessing diperoleh bahwa terdapat 1048 komentar positif dengan persentase $70.67 \%$ dan sisanya 435 komentar negatif dengan persentase $29.33 \%$ yang menggambarkan respons pengguna Instagram terhadap kebijakan Kemdikbud dalam memberikan bantuan kuota 
internet. Dalam kata lain, kata-kata tersebut merupakan kata-kata yang mewikili tanggapan atau respons masyarakat terhadap adanya bantuan kuota internet yang diberikan oleh Kemdikbud.

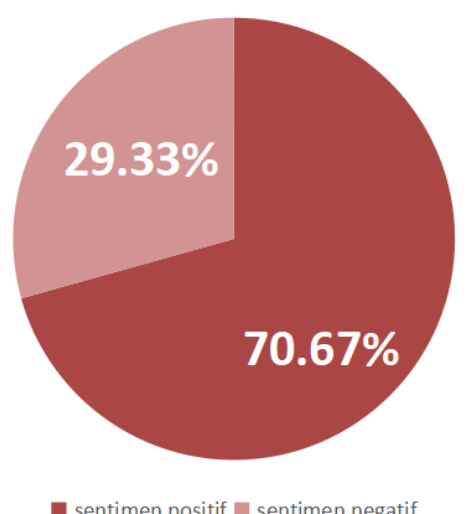

Gambar 5. Distribusi persentase respons/komentar pengguna Instagram berdasarkan kelas sentimen positif dan negatif

Gambar 5 menunjukkan bahwa komentar pada sentimen positif tiga kali lebih banyak dibandingkan dengan komentar pada sentimen negatif. Komentar pada sentimen negatif merupakan kata-kata tertentu yang digunakan oleh pengguna Instagram dalam menunjukkan respons yang berupa pengaduan terkait bantuan kuota internet yang tak kunjung didapat, cara mendapatkan bantuan kuota internet yang pada awal munculnya kebijakan tersebut teknisnya belum dipublikasikan secara rinci, sulitnya tahap verifikasi dan validasi (verval) data nomor ponsel bagi para operator sekolah, serta kendala pemberian kuota untuk guru di sekolah yang langsung diberikan sesuai dengan data yang tertera di dapodik padahal tidak semua data di dapodik sudah update. Sementara itu, komentar pada sentimen positif merupakan kata-kata yang digunakan dalam menunjukkan respons pengguna Instagram terkait bantuan kuota internet yang berupa ungkapan rasa bersyukur serta berterimakasih kepada pihak Kemdikbud atas bantuan kuota gratis, laporan bahwa bantuan kuota internet sudah masuk ke nomor siswa atau peserta didik, pertanyaan mengenai pemberian kuota yang berupa kuota belajar dan reguler, serta saran-saran yang membangun terkait peningkatan kapasitas server pusat agar mempermudah pendataan nomor telepon seluler peserta didik, sekaligus di dalamnya proses verifikasi dan validasi.

\section{Klasifikasi Respons Masyarakat menggunakan Support Vector Machine (SVM)}

1. Pembentukan Data Testing dan Training

Data training yang digunakan dalam penelitian ini sebanyak $75 \%$ dan $25 \%$ sisanya digunakan sebagai data testing. Tabel 4 menunjukkan persentase sentimen positif dan negatif yang akan digunakan dalam pengklasifikasian pada tahap berikutnya.

Tabel 4. Distribusi Persentase Komentar Berdasarkan Sentimennya pada Beberapa Dataset

\begin{tabular}{l|c|c|c}
\hline Sentimen & $\begin{array}{c}\text { Data } \\
\text { awal }\end{array}$ & $\begin{array}{c}\text { Data } \\
\text { Training }\end{array}$ & $\begin{array}{c}\text { Data } \\
\text { Test }\end{array}$ \\
\hline Positif & 70.67 & 69.78 & 73.32 \\
\hline Negatif & 29.33 & 30.22 & 26.68 \\
\hline
\end{tabular}

\section{Hasil Klasifikasi SVM pada Data Training}

Setelah dilakukan analisis klasifikasi dengan menggunakan metode Support Vector Machine (SVM) didapatkan bahwa tipe SVM yang digunakan pada model yaitu tipe CClassification, dimana tipe ini digunakan untuk melakukan pengklasifikasian biner dan model pendekatan yang digunakan adalah SVMKernel Radial (Radial Basis Function). Untuk mengetahui seberapa akurat model SVM yang dihasilkan pada data training, maka perlu dilakukan pengujian dengan confussion matrix yang hasilnya ditampilkan pada tabel 5 .

Tabel 5. Confussion Matrix Model SVM Data Training

\begin{tabular}{c|c|c}
\hline \multirow{2}{*}{$\begin{array}{c}\text { Data } \\
\text { awal }\end{array}$} & \multicolumn{2}{|c}{ Prediksi } \\
\cline { 2 - 3 } positif & negatif \\
\hline Positif & 603 & 173 \\
\hline Negatif & 68 & 268 \\
\hline
\end{tabular}

Berdasarkan pengujian model SVM Radial (RBF) pada data training, didapatkan informasi bahwa tingkat akurasi klasifikasinya 
sebesar $78.33 \%$, sensitivitas sebesar $77.71 \%$, dan spesifisitas sebesar $79.76 \%$.

\section{Evaluasi Model SVM dengan Data Testing}

Evaluasi model SVM dapat dilakukan dengan menghitung tingkat akurasi, sensitivitas, dan spesifisitas. Berikut ditunjukkan melalui tabel 6 yang merupakan confussion matrix dari model yang digunakan pada data testing.

Tabel 6. Confussion Matrix Model SVM

\begin{tabular}{c|c|c}
\multicolumn{3}{c}{ Data Testing } \\
\hline \multirow{2}{*}{$\begin{array}{c}\text { Data } \\
\text { awal }\end{array}$} & \multicolumn{2}{|c}{ Prediksi } \\
\cline { 2 - 3 }$(1)$ & positif & negatif \\
\hline Positif & 213 & $(3)$ \\
\hline Negatif & 18 & 87 \\
\hline
\end{tabular}

Berdasarkan hasil evaluasi, diperoleh tingkat akurasi klasifikasi dengan menggunakan model SVM Radial (RBF) sebesar 79.67\%, sensitivitas sebesar $78.89 \%$, dan spesifisitas $81.82 \%$. Berdasarkan ketiga ukuran tersebut ditunjukkan bahwa model pengklasifikasian untuk respons pengguna Instagram terhadap kebijakan Kemdikbud tentang pemberian bantuan kuota internet dengan metode SVM sudah cukup baik. Terbukti dari tingkat akurasi yang dihasilkan lebih tinggi dibandingkan dengan tingkat akurasi yang dihasilkan pada pengujian model SVM Radial (RBF) yang menggunakan data training.

\section{Hasil Klasifikasi SVM pada Data Awal}

Tingkat akurasi, sensitivitas, serta spesifisitas yang dihasilkan pada evaluasi model SVM Radial (RBF) menggunakan data testing lebih baik dibandingkan dengan hasil pengujian klasifikasi model SVM pada data training. Sehingga, dapat dilakukan klasifikasi model SVM Radial (RBF) pada keseluruhan data (data awal) komentar yang didapatkan.

Tabel 7. Confussion Matrix Model SVM pada Data Awal

\begin{tabular}{c|c|c}
\hline \multirow{2}{*}{ Data } & \multicolumn{2}{|c}{ Prediksi } \\
\cline { 2 - 3 } awal & positif & negatif \\
\hline
\end{tabular}

\begin{tabular}{c|c|c}
\hline$(1)$ & $(2)$ & $(3)$ \\
\hline Positif & 827 & 221 \\
\hline Negatif & 86 & 349 \\
\hline
\end{tabular}

Berdasarkan hasil klasifikasi menggunakan SVM pada data awal, didapatkan informasi bahwa tingkat akurasi klasifikasinya sebesar $79.30 \%$, sensitivitas sebesar $78.91 \%$, dan spesifisitas sebesar $80.23 \%$.

\section{KESIMPULAN}

Respons masyarakat Instagram sebanyak 1483 komentar terhadap kebijakan Kemdikbud mengenai pemberian bantuan kuota internet selama masa pandemi COVID-19 diidentifikasi menjadi $70.67 \%$ sentimen positif dan $29.33 \%$ sentimen negatif. Kemudian respons tersebut diklasifikasikan menggunakan data awal (keseluruhan data), data training, dan data testing dengan model SVM Radial (RBF) menghasilkan rata-rata persentase komentar berupa sentimen positif sebanyak $61.5 \%$. Hal tersebut menunjukkan respons yang baik dan rasa berterimakasih para pengguna Instagram terhadap adanya kebijakan Kemdikbud mengenai pemberian bantuan kuota internet selama masa pandemi COVID-19. Sedangkan $38.5 \%$ lainnya merupakan komentar berupa sentimen negatif yang menunjukkan keluh kesah pasa pengguna Instagram terhadap kendala-kendala dalam kebijakan Kemdikbud mengenai pemberian bantuan kuota internet selama masa pandemi COVID-19. Model SVM Radian (RBF) mampu melakukan pengklasifikasian respons pengguna Instagram terkait pemberian bantuan kuota internet dengan cukup baik. Hal tersebut dibuktikan dengan nilai evaluasi model berupa tingkat akurasi sebesar $79.67 \%$, sensitivitas sebesar $78.89 \%$, dan spesifisitas sebesar $81.82 \%$. Dengan demikian, respons masyarakat yang salah satunya diwakili oleh pengguna media sosial seperti Instagram dapat menjadi sumber informasi dan data alternatif untuk menunjang evaluasi dan perbaikan kebijakan pemerintah yang sudah ada maupun pembuatan kebijakan pemerintah di masa yang akan datang. 


\section{SARAN}

Penulis menyarankan untuk penelitian selanjutnya dapat menggunakan sumber data yang jangkauannya lebih luas, tidak hanya berasal dari 1 akun saja, atau bahkan dapat mencakup beberapa media sosial seperti Twitter dan Facebook serta menggunakan metode supervised learning lainnya seperti Artificial Neural Network untuk menganalisis fenomenafenomena yang berasal dari internet sehingga mampu menghasilkan suatu pengetahuan baru.

\section{DAFTAR PUSTAKA}

[1] Buntoro, GA. 2016. "Analisis Sentimen Hatespeech pada Twitter Dengan Metode Naïve Bayes Classifier dan Support Vector Machine". Jurnal Dinamika Informatika Vol.5, No.2, September 2016. ISSN:1978-1660.

[2] Dong, Y dkk. 2007. "An Optimization Method For Selecting Parameters In Support Vector Machines". Sixth International Conference on Machine Learning and Applications (ICMLA 2007), Cincinnati, h. 1-6.

[3] Han, J \& Kamber, M. 2006. "Data Mining: Concepts and Techniques 2nd edition". United States of America: University of Illinois at UrbanaChampaign.

[4] Julianto, R dkk. 2017. "Analisis Sentimen Layanan Provider Telepon Seluler pada Twitter menggunakan Metode Nä̈ve Bayesian Classification". Journal of Big Data Analytic and Artificial Intelligence, Vol.3, No.1, Juni 2017, h.23-30.

[5] Kurniawan, A. 2020. "Scraping komentar instagram menggunakan selenium python". Medium, dilihat 30 September 2020,

$<$ https://medium.com/@Arifku_/scraping -komentar-instagram-menggunakanselenium-python-3de175b3249d>

[6] Kurniawan, B dkk. 2012. "Klasifikasi Konten Berita Dengan Metode Text Mining”. Jurnal Dunia Teknologi Informasi, Vol.1, No.1, 2014, h.14-19.
[7] Liu, B dkk. 2005. "Opinion Observer: Analyzing and Comparing Opinions on the Web". Proceedings of the 14th international conference on World Wide Web, May 2005, Ichiba, Japan, h.342351.

[8] Nooraeni, R dkk. 2020. “Analisis Sentimen Data Twitter Mengenai Isu RUU KPK dengan Metode Support Vector Machine (SVM)". Jurnal Informatika dan Komputer, Vol.22, No. 1, Maret 2020. PISSN:1410-5063, E-ISSN:2579-3500, h.55-60.

[9] Novantirani, A. 2015. "Analisis Sentimen pada Twitter Mengenai Penggunaan Transportasi Umum Darat dalam Kota dengan Metode Support Vector Machine”. Bandung: Universitas Telkom.

[10] Ohorella, NAT. 2019. "Support Vector Machine (SVM) dalam $R$ ". Medium, dilihat 4 Oktober 2020, <https://medium.com/@16611094/support -vector-machine-svm-dalam-r932c759aedb2>

[11] Pamungkas, EW \& Putri, DGP. 2016. “An Experimental Study of Lexicon-Based Sentiment Analysis on Bahasa Indonesia”. Proceeding of The 6th International Annual Engineering Seminar (InAES), Yogyakarta, Indonesia, h.28-31.

[12] Peng, W \& Park, DH. 2011 “Generate Adjective Sentiment Dictionary for Social Media Sentiment Analysis Using Constrained Nonnegative Matrix Factorization". Proceedings of the Fifth International AAAI Conference on Weblogs and Social Media, July 2011, Spain, h. 273-280.

[13] Pramana, Setia dkk. 2018. "Data Mining Dengan R: Konsep Serta Implementasi”. Bogor: In Media.

[14] Pudjiarti, E. 2016. "Prediksi Spam Email Menggunakan Metode Support Vector Machine dan Particle Swarm Optimization”. Jurnal Pilar Nusa Mandiri, Vol.XII, No.2, September 2016. ISSN:1978-1946, h. 171-181.

[15] Salsabila, NA dkk. 2018. "Colloquial Indonesian Lexicon”. 2018 International 
Conference on Asian Language Processing (IALP), Bandung, Indonesia, h. 226-229.

[16] Supriyadi. 2018. "Sentiment-Analysiswith-R". GitHub, dilihat 3 Oktober 2020, $<$ https://github.com/supriyd/SentimentAnalysis-with-R>

[17] Tala, FZ. 2003. "A Study of Stemming Effects on Information Retrieval in Bahasa Indonesia". The Netherlands: Institute for Logic, Language and Computation Universiteit van Amsterdam.

[18] Wahid, DH \& Azhari, SN. 2016. "Peringkasan Sentimen Esktraktif di Twitter Menggunakan Hybrid TF-IDFdan Cosine Similarity”. IJCCS, Vol.10, No. 2, July 2016. ISSN:1978-1520, h. 207-218. 